\title{
CHALLENGES TO EFFECTIVE INTEGRATED WATER RESOURCES MANAGEMENT: A REVIEW
}

\author{
Zuriyati Yusof
}

River Engineering and Urban Drainage Research Centre, Universiti Sains Malaysia Kampus Kejuruteraan Seri Ampangan, 14300 Nibong Tebal, Penang, Malaysia

\section{Noor Aida Saad}

River Engineering and Urban Drainage Research Centre, Universiti Sains Malaysia Kampus Kejuruteraan Seri Ampangan, 14300 Nibong Tebal, Penang, Malaysia

\begin{abstract}
ABSTACT
The water management sectors are frequently challenged by the Integrated Water Resources Management (IWRM) principle to disregard structural, domestic, police and administrative support during their implementation process. Therefore, the implementation of the IWRM can lead to conflict, provocation, confusion and downfall of integration. Water sectors are a hugely relevant issue to be handled with the integrated mechanism during water management interventions. The need to incorporate long-term visions and alignment of basin-sub-basins is therefore to be relied to by all main players, which should provide a strong financial basis and be focused to strong awareness of the river basin and its interrelationships. This paper discusses the regulatory framework of water management as the key pillar of a successful IWRM implementation. Comparison are made with countries selected based on the many efforts that have been made under water resource management.
\end{abstract}

Keywords: Intergrated Water Resources Management (IWRM), Sustainable management, Water resources

Cite this Article: Zuriyati Yusof and Noor Aida Saad, Challenges to Effective Integrated Water Resources Management: A Review, International Journal of Civil Engineering and Technology, 11(9), 2020, pp. 54-61.

https://iaeme.com/Home/issue/IJCIET?Volume=11\&Issue=9

\section{INTRODUCTION}

Climate change has been one of society's greatest problems for decades. Challenges such as climate change coupled with the impact of human activities mean that those responsible for water resource management are facing a difficult task [1-5]. Private and public stakeholders will endeavor to help establish ways to effectively manage the entire water cycle. Demand is 
growing across other areas following changes in consumption and output trends due to population, urbanization, agricultural and industrial expansion [3]. Chapter 18 of Agenda 21, Sustainable Development of the United Nation, stated that all States must develop the institutional basis of Integrated Water Resource Management (IWRM) and complete sections of all freshwater programs by 2025 [6]. IWRM is a comprehensive water management approach with scientific, environmental, financial and institutional implications. The IWRM concept presents a new water management challenge, which is expressed on the physical and ecological frontier of river basins and catchment areas. River basin is an important water resource management unit and the most appropriate geographic scale for water resource planning and management, particularly in IWRM [7]. To achieve the country's development goals and reach a future of sustainable human development, water challenges must be addressed. The way forward is to gain common understanding of different requirements and develop water management solutions that deliver the highest shared value to water resources among stakeholders in government, civil society, and the private sector [5]. This paper discusses challenges of efficient water resource management. Water management calls for effective governance to address water vulnerabilities and values, good management practices and social, economic, political and environmental conditions. By identifying the gap and differences in how to manage water resources effectively, good water governance can be achieved through these key elements, including equity, transparency, accountability, environmental and economic sustainability, stakeholder participation and empowerment, and responsiveness to socioeconomic development needs [8].

\section{REGULATORY FRAMEWORK FOR WATER RESOURCES MANAGEMENT}

The regulatory framework includes laws, regulations, and policies formally developed and approved by the government. The Federal Government governs the Water Resources Framework, which will implement various central and state institutions. The State's statutory body is a legal body authorized to enact legislation on behalf of the State concerned. As most countries indicate that water is to be managed by the state, the state is responsible for ensuring that water resources, river basins and coastal waters are sustained and effectively maintained, contributing to the state 's development and socio-economic activities. All water management institutions and citizens; government departments and agencies, academic bodies, civil society organizations, members of the various consumer sectors and the private entity should cooperate in water resource management. This is to create a transparent, integrated, inclusive water resource management framework [9-11]. This section defines and compares the regulatory structure to manage water resources in four countries. The countries were selected based on many efforts under water resource management. Different publications were also reported on water resources management in selected countries. Also, attention was given to the comparison between developed and developing countries. European Union and China are categorised as developed countries, while Malaysia and Vietnam are the developing countries of Southeast Asia.

\subsection{Constitution in Water Regulation Authority}

Each country regulates water under different regulations and acts, with the aim, in the best interests of the people as water consumers, of managing equal water supplies [12]. Water is regulated in China and India both under Water Law, European Union commits to the Water Framework Directive, Malaysia's water regulation is by Water Act and Vietnam water is govern by the Law on Water Resources. The constitution responsible to regulate water in Vietnam is given to the Government [11]. The Government conducts coherent water quality 
control, with the Ministry of Agriculture and Rural Development (MARD) has responsibility for performing the role in both water management and flood control. This responsibility has now been transferred to the Ministry of Natural Resources and Environment (MONRE), while MARD remains as the department of irrigation and supply for rural water. Its main responsibilities include endorsing the river basin general plan, water conservation and addressing flood and storm prevention. The task of the State is to establish and maintain a water resource use and protection policy, to establish rules, guidelines and regulations for the use and management of water resources, to issue water licenses, and to comply with legislation on infringements of water resources. Other countries assign the State as the authority to regulate water. The Government indicated that water is gazette under the State matter. State Enactment has been outlined and applied to all rivers between the States borders. The intention of the legislative is to ensure the continuity of policies that governs throughout the state, by operating at regional level and taking into account the irregularity of water resources in the state $[12,13]$. On the other hand, the Government is responsible for regulating issues relating to boundary waters, regulating international or interprovincial issues and all aspects of rivers and lakes that occur on federal land within the provinces $[2,7,14,15]$. The constitution in water regulation authority can be illustrated in Figure 1.

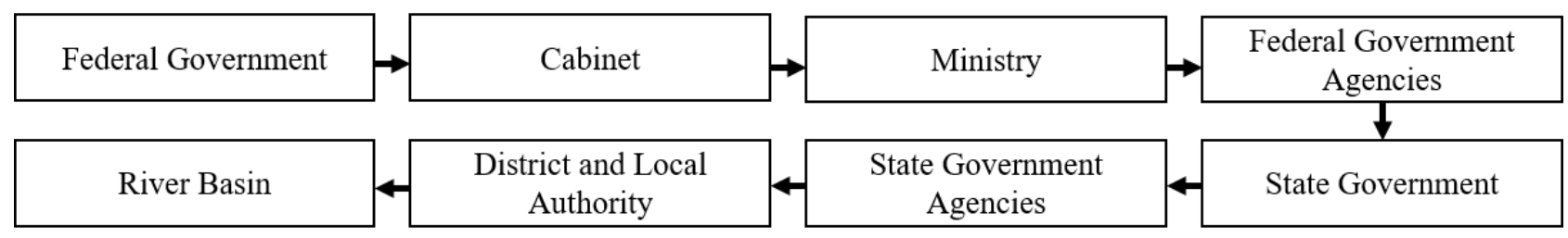

Figure 1 Regulatory Framework for River Basin Management

\subsection{Ministry Responsible to Water}

China put the responsible to water exclusively to one ministry which is the Ministry of Water Resources. The structure of the Ministry details down departments focusing on main areas of water resources management: Department of Planning and Programming, Department of Policy, Law and Regulations, Department of Water Resources Management, Department of Finance and Economics, Department of Personnel, Labor and Education, Department of Construction and Management, Department of International Cooperation, Science and Technology and Department of Water and Soil Conservation and Department of Irrigation, Drainage and Rural Water Supply [16,17]. Other countries held responsibility for water under single ministry with one or more responsibilities. European Union stating that each Member State is bound by its domestic water regulation and assigned ministry to accommodate the Directive, Malaysia with the Ministry of Environment and Water while Vietnam water management is under the Ministry of Natural Resources and Environment and the Ministry of Agriculture and Rural Development. It is appropriate to set up one or more water management implementation agencies, including allocation planning, monitoring of water rights, preparation of action plans and programs and compliance actions. The arrangements of these authorities and duties should ensure that there is no overlap of authority and responsibility. The entity must also be given to manage its administration and finances independently. This is to ensure that in the event of any problems and dispute, the matter can be resolved promptly without having to refer to various bureaucratic matters.

\subsection{River Basin Management}

The river basin is a geographical region defined by the water borders of both the ground and the surface of a water system that flows to a specific terminal [7]. Water laws in each country 
regulated water management to be an administrative unit under one river basin entity [18]. When the government delegated water resource management authority to the state, it is the state's responsibility to appoint a river basin authority for the management of its river basin. Assigning a river basin authority will deliver a more focused and systematic water-related frameworks. The principle of managing a river basin is to have security of water resources, a collaborative governance and to achieve water resources sustainability. This is to have a more integrated water management between all sectors and discipline. Literature-based, these countries has already established Integrated River Basin Management, which have been reviewed occasionally for better improvement in sustainable water resources management.

\subsection{Water resources Financial System}

Government adopts different economic methods to support and enhance economic growth. Natural resource utilization is regulated by taxes and permits [19]. The government is responsible for determining and monitoring resource use to ensure proper and adequate management. This is to ensure that natural resources are managed sustainably. As in water resources management context, fee and charges are levied for water use with specific user fees and licensing fees. It appeared that, under their own water regulations, each country stated the similar method for its water resources financial system. The regulations also require individuals and entities to acquire admission, license and permit from water use and water systems providers [11,20]. Water charges are some of the most important considerations for water resource management. A fixed reasonable fee rate imposed by the government must be properly analyzed to ensure the cost of financing water infrastructure services and maintenance is covered [11,21,22]. Water users should also be appreciated and encouraged as the key roles in water management that include operating, maintaining and imposing water charges $[11,23,24]$.

\subsection{Regulation and Enforcement of Water use}

A governance model is typically shaped by rules and regulations [23]. Each countries has outlined its regulations and enforcement of water use. It was clear the all regulations and enforcement of water are formed by the countries to preserve the public from contaminants and pollutants that are hazardous to human health. Natural resources such as water is affected by business activity in many different ways. These include problems such as, various kinds of pollution, soil conservation, protection against natural disasters and exploitation of natural resources that leads to major environment investment. China has successfully applied an emergency regulation technical framework to overcome the water pollution from the Southto-North Water Diversion Project. The structure comprised of four sub-models consisting of four emergency regulatory phases, including the identification of source, simulation and alert, emergency regulation and evaluation measures [25]. The emergency regulation to water is very encouraging so as to confront water pollution crisis during the construction of water infrastructure projects. In order to balance up the need between the society and the environment, regulation and enforcement it is crucial to comprehend with the abuse and dispute of the resources. For that purpose, detailed water legislation is needed in order to practice a transparent, effective and efficient water resources governance. To design, prepare and review water regulations is crucial important as many of those regulations occurred long time before [26]. Water uses need time to be made regularize with the new legislation. Offenses committed under the violations of law, pollution and unauthorized use of water are required to take legal action outlined in the water act and regulation such as levy fines for violation and jail terms. 


\section{CHALLENGES OF IMPLEMENTING THE INTEGRATED WATER RESOURCES MANAGEMENT}

Water resource management is a coordinating mechanism for water, land and other related resource production and management to optimize equal economic and social welfare without affecting sustainability of the ecosystem [27-29]. Many countries have accepted UN recommendations to implement sustainable use of water resources. A framework with documented water resource management blueprint requires a comprehensive water management action and mitigation plan outline. For river basin management, a program of measures should be presented to achieve environmental goals for each basin [30]. The blueprint should focus on effective implementation of water legislation, integrating water policy objectives into other policies and reducing the gap between water quantity and efficiency. This is to ensure that the quantity and quality of water is sufficient to meet people's needs and the country's economy development. Another crucial factor in water management is not just regulation, but a mechanism or strategy for enforcing such a regulation. Legislation should not therefore be confused with policy. When implementing a policy, law should be checked to identify where changes and improvements are needed.

\subsection{Lacking of Clear Direction}

A perfect water resources management framework listing down all of its objectives and action plans, would always faced hiccups through the implementation process. A weak framework will only causes confusion due to its poor content and guideline. The problems and delays of the European Union Water Directive Framework implementation is because the framework was very complicated and would create a lot of confusion and confrontation [10]. The framework also contains unclear terms and phrasing. Furthermore, most frameworks do not undertake the exact structure needed for its implementation. The elements of innovation proposed through new ideas and the improvement of existing ideas are often misunderstood by its core principles. This is because the interpretation of that innovation is carried out by those who are not in accordance with the task [23]. Obviously, a framework takes time to be understood as it contains variety of action plans, guidelines and directives that comprises various areas and responsibilities in water resources.

\subsection{Non-uniform Legislation and Water Ownership}

Since water governance structures are regulated within the federal and state level, there are numerous rules and legislation of rivers and water, of which varies between states and provinces [22]. These will create a never ending political negotiations on legal and policy dissimilarity, that will result in disagreement on water resource management [10,16,31]. Coordinating authorities at different level is very difficult when there is no absolute possession of the resources. Thereby, water conflicts would occur between ministries and agencies managing water [18,22,26,31]. Most federal and state agencies operate independently and separately from water resource management. Federal and state governments' varying focus on different but limited aspects of water resource management can lead to gaps and overlaps in their jurisdictions. Because of this contrast and complexity of both federal and state functions and tasks, the integration problem of policies in water resource management will remain unresolved. Cooperation between the various stakeholders would not have been possible if the objectives of water resource management were not fully integrated. 


\subsection{Overstated Framework}

A framework that sets unrealistic expectations and targets are often due to the lack of understanding of the main problems needed to be addressed. This is due to its design without looking into either idealistic and realistic method to achieve it. The inability to understand the technical and management complexity of the water management issue will make it more challenging to manage and monitor the framework. When a framework is not showing positive progress, it would caused shortfalls of confidence and acceptance by the stakeholders. This would become a huge hurdle to the implementation of the water management [10]. A successful framework looked ambitiously in the forefront of the future, while still looking at the difficult realities of the present. It should also incorporate a detailed knowledge and information of what needs to be done.

\section{CONCLUSION}

This paper concludes that water management structures should, irrespective of the challenges, undergo a reform aimed at improving efficiency in service provision, coverage, customer orientation and distribution equity in the sector. Sustainable and effective water management considers the water sector as part of a broader social, political and economic development framework that is able to influence and affect others and the overall context. There must be a major shift in water policy to emphasize conservation and demand management to secure long-term water supplies while fulfilling strict socio-economic, financial and environmental sustainability criteria and public health requirements. Stricter laws and regulations should be implemented to effectively manage clean river sustainability. Significant public participation, sound management and cost-effective resource utilization require the greatest attention of decision makers. Countries should periodically evaluate and improve their water resource management framework. This ensures that the framework remains practical and issues are resolved promptly during implementation. A robust, detailed action plan on water resources management would not work without strong political support and an implementation team with no passion for water sector improvements.

\section{ACKNOWLEDGEMENT}

The team would like to thank Universiti Sains Malaysia and Jabatan Perkhidmatan Awam Malaysia for funding and providing research grant for this study.

\section{REFERENCES}

[1] Chang, I. S., Zhao, M., Chen, Y., Guo, X., Zhu, Y., Wu, J., \& Yuan, T. (2020). Evaluation on the integrated water resources management in China's major cities-Based on City Blueprint ${ }^{\circledR}$ Approach. Journal of Cleaner Production, 121410.

[2] Yuan, L., He, W., Degefu, D. M., Liao, Z., Wu, X., An, M., \& Ramsey, T. S. (2020). Transboundary water sharing problem; a theoretical analysis using evolutionary game and system dynamics. Journal of Hydrology, 582, 124521.

[3] Al-Jawad, J. Y., Alsaffar, H. M., Bertram, D., \& Kalin, R. M. (2019). A comprehensive optimum integrated water resources management approach for multidisciplinary water resources management problems. Journal of environmental management, 239, 211-224.

[4] Huot, Y., Brown, C. A., Potvin, G., Antoniades, D., Baulch, H. M., Beisner, B. E., \& del Giorgio, P. A. (2019). The NSERC Canadian Lake Pulse Network: A national assessment of lake health providing science for water management in a changing climate. Science of The Total Environment, 695, 133668. 
[5] Lausier, A. M., \& Jain, S. (2019). Water resources stewardship in an era of rapid change. Water Security, 7, 100034.

[6] Le Page, M., Fakir, Y., \& Aouissi, J. (2020). Modeling for integrated water resources management in the Mediterranean region. In Water Resources in the Mediterranean Region (pp. 157-190). Elsevier.

[7] Ha, N. P. N., Tu, D. T., Toan, N. V., Mai, P. T., Seng, S., Keartha, C., \& Phyrom, S. (2013). River basin management in Vietnam: Sectoral and cross-boundary issues. Mekong Project, 4.

[8] Bagheri, A., \& Babaeian, F. (2020). Assessing water security of Rafsanjan Plain, IranAdopting the SEEA framework of water accounting. Ecological Indicators, 111, 105959.

[9] Skoulikaris, C., \& Zafirakou, A. (2019). River Basin Management Plans as a tool for sustainable transboundary river basins' management. Environmental Science and Pollution Research, 26(15), 14835-14848

[10] Giakoumis, T., \& Voulvoulis, N. (2018). The transition of EU water policy towards the water framework directive's integrated river basin management paradigm. Environmental management, 62(5), 819-831.

[11] Salman, S. M., \& Bradlow, D. D. (2006). Regulatory frameworks for water resources management: a comparative study. The World Bank.

[12] Pahl-Wostl, C., Knieper, C., Lukat, E., Meergans, F., Schoderer, M., Schütze, N., \& Thiel, A. (2020). Enhancing the capacity of water governance to deal with complex management challenges: A framework of analysis. Environmental Science \& Policy, 107, 23-35.

[13] Davis, J., Borisova, T., \& Olexa, M. T. (2018). [FE1043] An Overview of Florida Water Policy Framework and Institutions. EDIS, 2018(6).

[14] Akhtar, S. M., \& Iqbal, J. (2017). Assessment of emerging hydrological, water quality issues and policy discussion on water sharing of transboundary Kabul River. Water Policy, 19(4), 650-672.

[15] Becklumb, P. (2013). Federal and provincial jurisdiction to regulate environmental issues. Library of Parliament $=$ Bibliothèque du Parlement.

[16] Yan, F., Daming, H., \& Kinne, B. (2006). Water resources administration institution in China. Water Policy, 8(4), 291-301.

[17] China Ministry of Water Resources. (n.d). http://www.mwr.gov.cn/ english/ aboutmwr.html

[18] Delipınar, Ş., \& Karpuzcu, M. (2017). Policy, legislative and institutional assessments for integrated river basin management in Turkey. Environmental Science \& Policy, 72, 20-29.

[19] van der Heijden, J. (2017). Urban sustainability and resilience. Regulatory theory: foundations and applications, 725-740.

[20] Tsur, Y. (2020). Optimal water pricing: Accounting for environmental externalities. Ecological Economics, 170, 106429.

[21] Sibly, H. (2019). Urban water policy when environment inflows are uncertain. Water Resources and Economics, 100149.

[22] Elfithri, R., \& Mokhtar, M. B. (2018). Integrated Water Resources Management in Malaysia: Some Initiatives at the Basin Level. In Water Resources Management (pp. 231-244). Springer, Singapore.

[23] Ramanathan, R., He, Q., Black, A., Ghobadian, A., \& Gallear, D. (2017). Environmental regulations, innovation and firm performance: A revisit of the Porter hypothesis. Journal of Cleaner Production, 155, 79-92.

[24] Shortle, J. (2017). Policy Nook: "Economic Incentives for Water Quality Protection". Water Economics and Policy, 3(02), 1771004. 
[25] Li, P., \& Qian, H. (2018). Water resources research to support a sustainable China.

[26] Shah, T., Makin, I., \& Sakthivadivel, R. (2002). The Challenges of Integrated River Basin Management in India. Water Policy Briefing, (3).

[27] Water, U. N. (2015). The United Nations world water development report 2015: water for a sustainable world. UNESCO.

[28] Water, U. N. (2014). International decade for action, "Water for Life', 2005-2015. Focus Areas: Water and Sustainable Development. http://www. un. org/waterforlifedecade/water_ and_sustainable_development. shtml (accessed 26/04/2016).

[29] WWAP - World Water Assessment Programme. (2003). The United Nations World Water Development Report: Water for People Water for life Paris: UNESCO, and London: Earthscan.

[30] Pulido-Velazquez, M., \& Ward, F. A. (2017). Comparison of Water Management Institutions and Approaches in the United States and Europe-What Can We Learn From Each Other?. In Competition for Water Resources (pp. 423-441). Elsevier.

[31] Shrubsole, D., Walters, D., Veale, B., \& Mitchell, B. (2017). Integrated Water Resources Management in Canada: the experience of watershed agencies. International Journal of Water Resources Development, 33(3), 349-359.

[32] Yap, C. K., Peng, S. H. T., \& Leow, C. S. (2019). Contamination in Pasir Gudang Area, Peninsular Malaysia: What can we learn from Kim Kim River chemical waste contamination. Journal of Humanities and Education Development (JHED), 1(2), 84-87. 